\title{
Management of Sclerotinia Blight of Peanut with the Biological Control Agent Coniothyrium minitans
} D. E. Partridge, Former Graduate Research Assistant, T. B. Sutton, Professor, Department of Plant Pathology,
D. L. Jordan, Associate Professor, Department of Crop Science, V. L. Curtis, Agricultural Research Specialist, and
J. E. Bailey, Professor (deceased), Department of Plant Pathology, North Carolina State University, Raleigh 27695

\begin{abstract}
Partridge, D. E., Sutton, T. B., Jordan, D. L., Curtis, V. L., and Bailey, J. E. 2006. Management of Sclerotinia blight of peanut with the biological control agent Coniothyrium minitans. Plant Dis. 90:957-963.

Sclerotinia blight, caused by Sclerotinia minor, is an important disease of peanut in North Carolina. The effectiveness of Coniothyrium minitans, a mycoparasite of sclerotia of Sclerotinia spp., was studied in a 5-year field experiment and in eight short-term experiments in northeastern North Carolina. The 5-year experiment was initiated in November 1999 to evaluate the effectiveness of repeated soil applications of $C$. minitans (commercial formulation, Contans WG) at 2 and $4 \mathrm{~kg} \mathrm{ha}^{-1}$ in reducing Sclerotinia blight. In addition, individual commercial peanut fields were selected in 2001 and 2002 to evaluate a single application of $C$. minitans at $4 \mathrm{~kg} \mathrm{ha}^{-1}$. No differences were found between the 2 and $4 \mathrm{~kg} \mathrm{ha}^{-1}$ rates of $C$. minitans in reducing Sclerotinia blight. In 2002, there was less disease in plots receiving applications of $C$. minitans for either 1 or 3 years compared with the nontreated control; whereas, in 2003, C. minitans applications for 1,2 , or 3 years reduced disease and the number of sclerotia isolated from soil. A single application of $C$. minitans reduced sclerotia in only two of the eight short-term experiments. The integration of consecutive years of soil applications of $C$. minitans at $2 \mathrm{~kg} \mathrm{ha}^{-1}$ with moderately resistant cultivars and fungicide applications may aid in the management of Sclerotinia blight in peanut.
\end{abstract}

Additional keywords: disease control, fluazinam

Sclerotinia blight, caused by the soilborne fungus Sclerotinia minor Jagger, is an important disease of peanut (Arachis hypogaea L.). This disease first was reported in Virginia in 1971 and North Carolina in 1972 (32). Since then, it has spread to all the major peanut-producing counties in North Carolina and also is found in Texas, Oklahoma, and New Mexico $(5,46)$. During favorable conditions for Sclerotinia blight, peanut farmers can lose up to $50 \%$ yield as a result of the disease (31). After passage of the 2002 Farm Bill, the market value of Virginia-type peanut, the main peanut type grown in North Carolina, fell from $\$ 600$ per ton to the current loan rate of $\$ 355$ per ton. The requirement of calcium and intensive use of chemicals for disease control cause producers in the Virginia-North Carolina region to have a higher production cost than most growers in the United States. Fungicides for control of Sclerotinia blight alone can cost producers as much as \$104 per hectare for a single application, with up to three appli-

Corresponding author: D. Partridge

E-mail: departri@vt.edu

Accepted for publication 22 February 2006.

DOI: 10.1094/PD-90-0957

(C) 2006 The American Phytopathological Society cations made in a season. Consequently, there is a pressing need to reduce the cost of managing Sclerotinia blight.

Overwintering sclerotia of $S$. minor in the soil provide the primary inoculum for Sclerotinia blight on peanut. Sclerotia of $S$. minor germinate myceliogenically, producing a mass of mycelium that directly penetrates peanut stem, leaf, peg, and pod tissues, initiating disease $(21,33)$. As Sclerotinia blight develops in the peanut canopy, numerous sclerotia are produced in and on diseased tissue. Sclerotia then are shed into the soil and increase the inoculum density of the pathogen, which subsequently is available in future growing seasons.

Rotation sequence is very important in managing diseases in peanut (30). Cylindrocladium black rot (CBR; caused by Cylindrocladium parasiticum) was found to increase in peanut fields when crop rotation included soybean (Glycine max (L.) Merr.) or when peanut was cropped continuously, but not when a nonhost crop was used in the rotation $(19,38)$. However, long-term rotations with nonhost crops such as corn (Zea may L.) and cotton (Gossypium hirsutum L.) have shown limited effectiveness in controlling Sclerotinia blight on peanut (33) because the sclerotia are able to remain viable for as many as 4 years in the soil $(1,26)$. Cvs. Perry, VA-C 92R, and VA98R have partial resistance; however, currently there are no Virginiatype cultivars with complete resistance to Sclerotinia blight (37). Although partial resistance and cultural methods provide limited control, the fungicides fluazinam (Omega 500F; Syngenta Crop Protection, Greensboro, NC) and boscalid (Endura; BASF Corp. Research Triangle Park, NC) are effective if applied properly $(30,39,40)$. These fungicides and host plant resistance are aimed at reducing disease development, but do not directly reduce the population of sclerotia in soil.

A number of microorganisms have been reported to parasitize sclerotia of Sclerotinia spp., including Coniothyrium minitans Campbell. C. minitans first was identified as a mycoparasite of sclerotia of Sclerotinia spp. by Campbell in 1947, when isolated from S. sclerotiorum (9). Subsequently, a number of studies have shown that sclerotia of Sclerotinia spp. in soil are readily infected and colonized by C. minitans $(14-16,25,42,47)$ and have demonstrated the effectiveness of $C$. minitans in controlling S. sclerotiorum in several crops in the greenhouse and field $(6,7,14,23,24,48,49)$ and, in one case, the effects have been shown to be long term (12). A spore suspension of $C$. minitans applied across field crops infected by $S$. sclerotiorum at the first appearance of apothecia resulted in a reduced population of sclerotia in soil at the end of a 7-year period even when susceptible crops were planted (12). Less information is known about the effectiveness of $C$. minitans on $S$. minor. Adams (1) reported that the viability of sclerotia of $S$. minor declined when soaked in a spore suspension of $C$. minitans but was not affected when spores of C. minitans were applied to soil containing sclerotia of $S$. minor. However, studies in Europe and New Zealand have reported the effectiveness of $C$. minitans in controlling disease caused by $S$. minor in lettuce production $(35,41)$. If $C$. minitans is active on $S$. minor, as has been found in some studies, then it may provide a way to reduce sclerotia numbers in peanut fields heavily infested by $S$. minor, thereby reducing losses.

The objective of this study was to determine the effectiveness of soil application of C. minitans, applied as Contans WG, in reducing the sclerotial population of $S$. minor and subsequent disease in peanut while integrating it with current cultivars and chemical treatments. 


\section{MATERIALS AND METHODS}

Long-term field site. A commercial peanut field near Gatesville, NC with a long-term history of peanut production and presence of Sclerotinia blight was selected for this study in 1999. The same field and the plots defined within it were used through the 2003 season. The rotation sequence in this field from 1998 to 2003 was peanut, cotton, cotton, peanut, peanut, and peanut.

C. minitans, commercial formulation Contans WG strain CON/M/91-08, with a minimum of $1 \times 10^{9} \mathrm{CFU} \mathrm{g}^{-1}$ (Prophyta Biologischer Pflanzenschutz $\mathrm{GmbH}$, Germany), was applied at 2 and $4 \mathrm{~kg} \mathrm{ha}^{-1}$ each for 1,2 , or 3 consecutive years (Table 1). Soil applications were made across crop residue on the soil surface with an $\mathrm{N}$ $\mathrm{kPa}$ and aqueous suspension at 142 liters/ha using hollow cone nozzles spaced $31 \mathrm{~cm}$ apart. The first application of $C$. minitans was made after cotton harvest on 3 December 1999 and repeated on 9 February 2001, establishing the one- and twoconsecutive-year soil treatments. C. minitans was applied again on 12 November 2001 following the first year of peanut, establishing the final one-, two-, and threeconsecutive-year treatments (Table 1).

Virginia-type peanut cvs. NC-V 11 (susceptible to Sclerotinia blight; 37 ) and Perry (moderately resistant to Sclerotinia blight; pressurized tractor-mounted sprayer at 276

37) were planted on 2 May 2001, 16 May 2002, and 18 June 2003. Fluazinam at $0.625 \mathrm{~kg}$ a.i. $\mathrm{ha}^{-1}$ was applied according to the weather-based Sclerotinia advisory warning system (28-30) using the $\mathrm{N}$ pressurized tractor-mounted sprayer described previously. The interval between fluazinam sprays was no shorter than 3 weeks, no more than three applications were made per year, and a 30-day preharvest interval was used (Table 2). Standard cultural and pest management practices such as tillage, fertilization, herbicide and insecticide applications, and fungicide applications to control early leaf spot (Cercospora arachidicola) and southern stem rot (Sclerotium rolfsii) were used as recommended by the North Carolina Cooperative Extension Service (19).

The experimental design was a split plot. Main-plot factors consisted of Coniothyrium minitans application at 2 and $4 \mathrm{~kg} \mathrm{ha}^{-1}$ each applied in one, two, or three consecutive years and a nontreated control (Table 1). Main plots were $29 \mathrm{~m}$ wide (28 rows) by $41 \mathrm{~m}$ long with 4.6-m alleys. Subplot factors consisted of combinations of the two cultivars (NC-V 11 and Perry) and two fluazinam rates $\left(0\right.$ and $0.625 \mathrm{~kg}$ a.i. ha $\left.{ }^{-1}\right)$. Subplots were $9 \mathrm{~m}$ wide (14 rows) by $18 \mathrm{~m}$ long, with the two center rows used for disease and pod yield evaluations.

Disease and yield assessment. Disease ratings were initiated in July each year and

Table 1. Main plot treatments applied in long-term study located in Gatesville, NC

\begin{tabular}{lcccc}
\hline & \multicolumn{4}{c}{ Coniothyrium $_{\text {minitans }}^{\mathbf{z}}$} \\
\cline { 2 - 5 } Treatment & Rate $\left(\mathbf{k g ~ h a}^{\mathbf{- 1}}\right)$ & Fall 1999 & Fall 2000 & Fall 2001 \\
\hline C. minitans & 2 & Yes & Yes & Yes \\
C. minitans & 4 & Yes & Yes & Yes \\
C. minitans & 2 & No & Yes & Yes \\
C. minitans & 4 & No & Yes & Yes \\
C. minitans & 2 & No & No & Yes \\
C. minitans & 4 & No & No & Nes \\
Control & NA & No & No & No \\
\hline
\end{tabular}

${ }^{\mathrm{z}}$ C. minitans applied as Contans WG (Prophyta Biologischer Pflanzenschutz GmbH, Germany). taken biweekly, with a final disease assessment taken just prior to harvest. The center two rows in each subplot each were divided into $6030-\mathrm{cm}$ long increments per row. Sclerotinia blight incidence was estimated by counting the number of $30-\mathrm{cm}$ increments showing signs of $S$. minor or symptoms of Sclerotinia blight (8). Area under disease progress curve (AUDPC) for each treatment was calculated as a measure of the cumulative incidence of Sclerotinia blight during the season (36).

Plants were dug based on mesocarp color determination (50) and vines inverted. Peanut plants were combined with conventional harvesting equipment from the two center rows of each plot on 22 October 2001, 8 November 2002, and 10 November 2003. A 500-g sample of pods from each plot was collected in 2002 to determine the percentages of extra large kernels (\%ELK), total sound mature kernels (\%TSMK), and fancy pods (\%FP) using United States Department of Agriculture Grading Service Guidelines (45).

Data were subjected to analysis of variance using the PROC GLM procedure of SAS (version 8; SAS Institute Inc. Cary, NC) for AUDPC, pod yield, \%TSMK, $\%$ ELK, and \%FP. Means for appropriate treatment main effects and interactions were separated using Fisher's protected least significant difference test at $P \leq 0.05$. Contrast statements were used to separate rate and yearly effects of $C$. minitans treatments at $P \leq 0.05$.

Sclerotia isolation and mycoparasitism. Soil samples were taken across main plots to determine populations of $S$. minor on 11 September and 10 October in 2002 and 16 September and 16 October in 2003. Soil samples were taken under the peanut canopy in each plot. The top $12 \mathrm{~cm}$ of soil was sampled with a shovel that removed soil cores $(10 \mathrm{~cm}$ in diameter) from four locations in each plot, which then were combined into one sample. Sub-

Table 2. Field experiments (Exp), locations (loc), cultivars, and dates of planting, Coniothyrium minitans soil incorporation, fluazinam application, and harvest

\begin{tabular}{|c|c|c|c|c|c|c|c|}
\hline \multirow[b]{2}{*}{ Exp, loc, year } & \multirow[b]{2}{*}{ Cultivar } & \multirow[b]{2}{*}{ Planting } & \multirow[b]{2}{*}{ C. minitans ${ }^{\mathrm{y}}$} & \multicolumn{3}{|c|}{ Fluazinam application $^{z}$} & \multirow[b]{2}{*}{ Harvest } \\
\hline & & & & 1st & 2nd & 3rd & \\
\hline \multicolumn{8}{|l|}{ Long-term } \\
\hline Gatesville & & & 3 December 1999 & & & & \\
\hline 2001 & NC-V 11, Perry & 2 May & 9 February 2001 & 26 July & 29 August & 22 October & 22 October \\
\hline 2002 & NC-V 11, Perry & 16 May & 12 November 2001 & 30 July & 12 September & $\ldots$ & 8 November \\
\hline 2003 & Perry & 18 June & $\ldots$ & 21 August & 10 September & $\ldots$ & 10 November \\
\hline \multicolumn{8}{|l|}{ Short-term } \\
\hline \multicolumn{8}{|l|}{2001} \\
\hline Windsor & NC-V 11, Perry & 10 May & 15 January 2001 & 25 July & 23 August & $\ldots$ & 5 October \\
\hline Tyner & VA 98R & 12 May & 15 January 2001 & 25 July & 23 August & $\ldots$ & 2 October \\
\hline Scotland Neck & NC-V 11, Perry & 8 May & 15 January 2001 & 25 July & 21 August & $\ldots$ & 16 October \\
\hline Jackson & NC-V 11, Perry & 7 May & 15 January 2001 & 24 July & 30 August & $\ldots$ & 3 October \\
\hline Hertford & VA 98R & 10 May & 15 January 2001 & 25 July & 23 August & $\ldots$ & 2 October \\
\hline \multicolumn{8}{|l|}{2002} \\
\hline Tyner & NC-V 11, Perry & 8 May & 21 November 2001 & 31 July & 04 September & $\ldots$ & \\
\hline Corapeake & NC-V 11, Perry & 15 May & 12 November 2001 & 30 July & 11 September & $\ldots$ & 8 November \\
\hline Gatesville & NC-V 11, Perry & 28 May & 22 November 2001 & 31 July & 06 September & $\ldots$ & 9 November \\
\hline
\end{tabular}

${ }^{\text {y }}$ C. minitans applied as Contans WG (Prophyta Biologischer Pflanzenschutz GmbH, Germany).

${ }^{\mathrm{z}}$ Fluazinam formulated as Omega 500F (Syngenta Crop Protection, Greensboro, NC) and applied at $0.625 \mathrm{~kg}$ a.i. ha ${ }^{-1}$. 
samples of $500 \mathrm{~g}$ were subjected to a modified soil elutriation technique to trap sclerotia on a $425-\mu \mathrm{m}$ sieve placed in a four-unit semiautomatic elutriator and allowed to sieve for $8 \mathrm{~min}$ (34). Sieves used included a U.S. standard number 10 sieve (2-mm opening) nested on top of U.S. number 35 sieve (425- $\mu$ m opening). The organic matter collected on the sieve was dried at room temperature $\left(22^{\circ} \mathrm{C}\right)$ for $24 \mathrm{~h}$ and then placed in $5^{\circ} \mathrm{C}$ until enumeration of sclerotia. Sclerotia in each sample were isolated from organic matter and enumerated under a stereomicroscope. Sclerotia viability and infection by $C$. minitans were determined after surface disinfesting in $15 \% \mathrm{NaOCl}$ for $30 \mathrm{~s}$; then, sclerotia were rinsed in sterilized distilled water, plated on potato dextrose agar (PDA) amended with tetracycline (25 mg liter $^{-1}$ ), and incubated at $18^{\circ} \mathrm{C}$ for 14 days. The number of sclerotia showing mycelial growth, whether or not they were infected by $C$. minitans, were considered viable. The percent sclerotia infected by $C$. minitans included both viable and nonviable sclerotia.

Sclerotia baiting. An isolate of $S$. minor (\#20, obtained from Dr. Barbara Shew, North Carolina State University; [13]) originally obtained from a diseased peanut plant in Gates County, NC, was used to produce sclerotia required for baiting. The sclerotia were produced on carrot disks that were incubated for 30 days, separated, and dried at room temperature $\left(22^{\circ} \mathrm{C}\right)$ prior to placement in terylene net bags. Twenty sclerotia $(0.03 \mathrm{~g})$ were placed in bags, which then were buried $10 \mathrm{~cm}$ below the surface of the soil underneath the peanut canopy. Four bags were buried in each main plot in the long-term field study on
23 July 2002 and 25 July 2003. Following burial for $2,4,8$, or 12 weeks, the sclerotia baits were recovered on 7 and 21 August, 9 September, and 10 October in 2002 and 5 and 21 August, 16 September, and 6 October in 2003. The sclerotia remaining in each bag were surface disinfested and plated on PDA amended with tetracycline as described previously for determination of viability and/or infection by $C$. minitans and other fungi.

Short-term field studies. Experiments examining single-year applications of $C$. minitans were conducted at five locations in 2001 and at three locations in 2002 in North Carolina (Table 2). Eight treatments were established at each location to examine the interactions between soil incorporation of $C$. minitans, cultivar (Perry or NC$\mathrm{V} 11$ ), and fungicide on the development of Sclerotinia blight in peanut, except at two locations, where only cv. VA 98R was planted. Assessments of disease incidence; sclerotial isolation, viability, and infection by $C$. minitans; and peanut yield and quality were the same as described for the long-term field site. Six of the short-term field sites had a split-plot experimental design with six replicates. $C$. minitans treatments were main plots and fungicidecultivar treatments were subplots. Only one peanut cultivar (VA 98R) was planted in plots in Tyner and Hertford in 2001, resulting in a randomized complete block design of $C$. minitans treatment by fungicide. Data for AUDPCs, sclerotial number, viability and infection, and peanut yield and market grade characteristics were subjected to analysis of variance appropriate for each factorial treatment arrangement. Means for appropriate treatment main effects and interactions were sepa- rated using Fisher's protected least significant difference test at $P \leq 0.05$.

\section{RESULTS}

Long-term field site. Interactions among whole-plot treatments of C. minitans and subplot treatments of fungicide and cultivars on the AUDPC for Sclerotinia blight incidence were not significant (Table 3). However, there were several significant interactions between the main effects on peanut yield in 2001 and 2002 (Table 3). Further examination of the simple effects on yield found that they were not significant; therefore, the mean yield data are presented for each main effect only. Contrasts were used to separate the effects of $C$. minitans rate and years of application (Table 3). Less disease, as reflected by the AUDPC, developed in the moderately resistant cv. Perry than in very susceptible cv. NC-V 11 in both 2001 and 2002 (Table 4). In 2003, only Perry was planted due to heavy rains, which flooded the plots and necessitated replanting Seed of NC-V 11 was not commercially available for replanting. Fluazinam applied according to the Sclerotinia blight advisory reduced disease in all years (Table 4). In 2001, there was no significant difference between no $C$. minitans and $C$. minitans rates of 2 or $4 \mathrm{~kg} \mathrm{ha}^{-1}$ (Table 4). The application of $C$. minitans did not affect yield in 2001 (Table 4). C. minitans at 2 or $4 \mathrm{~kg} \mathrm{ha}^{-1}$ reduced disease across both cultivars in 2002 and on Perry in 2003 (Table 4). Peanut pod yield was highest in plots treated with $C$. minitans at $4 \mathrm{~kg} \mathrm{ha}^{-1}$ in 2002; however, in 2003, all plots treated with $C$. minitans had lower yield compared with the nontreated control (Table 4).

Table 3. Summary of analyses of variance for main effects of Coniothyrium minitans treatment, fungicide, cultivar, their interactions, and contrasts of $C$. minitans treatment on Sclerotinia disease incidence as measured by the mean area under disease progress curve (AUDPC) and peanut yield in long-term field study for 2001, 2002, and $2003^{z}$

\begin{tabular}{|c|c|c|c|c|c|c|c|c|c|c|c|c|c|}
\hline \multirow[b]{3}{*}{ Source } & \multirow[b]{3}{*}{ df } & \multicolumn{4}{|c|}{2001} & \multicolumn{4}{|c|}{2002} & \multicolumn{4}{|c|}{2003} \\
\hline & & \multicolumn{2}{|c|}{ AUDPC } & \multicolumn{2}{|c|}{ Yield } & \multicolumn{2}{|c|}{ AUDPC } & \multicolumn{2}{|c|}{ Yield } & \multicolumn{2}{|c|}{ AUDPC } & \multicolumn{2}{|c|}{ Yield } \\
\hline & & $\boldsymbol{F}$ & $\operatorname{Pr}>\boldsymbol{F}$ & $\boldsymbol{F}$ & $\operatorname{Pr}>\boldsymbol{F}$ & $\boldsymbol{F}$ & $\operatorname{Pr}>\boldsymbol{F}$ & $\boldsymbol{F}$ & $\operatorname{Pr}>\boldsymbol{F}$ & $F$ & $\operatorname{Pr}>\boldsymbol{F}$ & $F$ & $\operatorname{Pr}>\boldsymbol{F}$ \\
\hline Rep & 3 & 0.97 & $\mathrm{~ns}$ & 6.06 & $* *$ & 0.48 & $\mathrm{~ns}$ & 0.36 & $\mathrm{~ns}$ & 7.48 & $* * *$ & 7.48 & $* * *$ \\
\hline Contans treatment & 6 & 1.46 & $\mathrm{~ns}$ & 1.34 & $\mathrm{~ns}$ & 7.74 & $* *$ & 1.20 & $\mathrm{~ns}$ & 2.62 & ns & 2.62 & ns \\
\hline Fungicide (fung) & 1 & 8.79 & $* *$ & 7.77 & ** & 26.12 & $* * * *$ & 1.45 & ns & 295.73 & $* * * *$ & 295.73 & $* * * *$ \\
\hline Cultivar (cult) & 1 & 25.08 & $* * * *$ & 2.05 & $\mathrm{~ns}$ & 91.42 & $* * * *$ & 1.40 & $\mathrm{~ns}$ & - & - & - & - \\
\hline Fung $\times$ cult & 1 & 0.80 & $\mathrm{~ns}$ & 0.13 & $\mathrm{~ns}$ & 0.32 & ns & 4.88 & $*$ & - & - & - & - \\
\hline Contans $\times$ fung & 6 & 0.77 & $\mathrm{~ns}$ & 3.01 & $*$ & 0.48 & $\mathrm{~ns}$ & 2.14 & $\mathrm{~ns}$ & 0.86 & $\mathrm{~ns}$ & 0.86 & $\mathrm{~ns}$ \\
\hline Contans $\times$ cult & 6 & 0.91 & $\mathrm{~ns}$ & 0.75 & $\mathrm{~ns}$ & 1.99 & $\mathrm{~ns}$ & 2.29 & $*$ & - & - & - & - \\
\hline Contans $\times$ fung $\times$ cult & 7 & 0.37 & $\mathrm{~ns}$ & 2.86 & $*$ & 1.70 & ns & 1.27 & ns & - & - & - & - \\
\hline \multicolumn{14}{|l|}{ Contrasts } \\
\hline Contans year & 1 & 0.41 & $\mathrm{~ns}$ & 1.09 & $\mathrm{~ns}$ & 19.04 & $* * *$ & 0.39 & $\mathrm{~ns}$ & 38.84 & $* * * *$ & 38.84 & $* * * *$ \\
\hline Control vs. 3 years & 1 & - & - & - & - & 26.35 & $* * *$ & 0.15 & $\mathrm{~ns}$ & 23.61 & $* * * *$ & 23.61 & $* * * *$ \\
\hline Control vs. 2 years & 1 & 0.04 & $\mathrm{~ns}$ & 1.43 & $\mathrm{~ns}$ & 3.66 & ns & 2.32 & $\mathrm{~ns}$ & 27.62 & $* * * *$ & 27.62 & $* * * *$ \\
\hline Control vs. 1 year & 1 & 4.05 & $*$ & 0.06 & $\mathrm{~ns}$ & 6.71 & $*$ & 1.52 & $\mathrm{~ns}$ & 36.89 & $* * * *$ & 36.89 & $* * * *$ \\
\hline 1 year vs. 2 years & 1 & 3.67 & $\mathrm{~ns}$ & 0.69 & ns & 0.46 & $\mathrm{~ns}$ & 0.09 & ns & 0.67 & ns & 0.67 & ns \\
\hline 1 year vs. 3 years & 1 & - & - & - & - & 6.47 & $*$ & 2.63 & ns & 1.48 & ns & 1.48 & ns \\
\hline 2 years vs. 3 years & 1 & - & - & - & - & 10.36 & $* *$ & 3.67 & ns & 0.16 & ns & 0.16 & ns \\
\hline Contans rate & 1 & 1.46 & $\mathrm{~ns}$ & 0.47 & $\mathrm{~ns}$ & 14.35 & $* *$ & 1.88 & $\mathrm{~ns}$ & 42.20 & $* * * *$ & 42.20 & $* * * *$ \\
\hline Control vs. $2 \mathrm{~kg} \mathrm{ha}^{-1}$ & 1 & 0.34 & $\mathrm{~ns}$ & 1.28 & $\mathrm{~ns}$ & 14.21 & $* *$ & 0.08 & $\mathrm{~ns}$ & 35.65 & $* * * *$ & 35.65 & $* * * *$ \\
\hline Control vs. $4 \mathrm{~kg} \mathrm{ha}^{-1}$ & 1 & 1.50 & $\mathrm{~ns}$ & 0.09 & ns & 10.68 & $* *$ & 4.02 & $\mathrm{~ns}$ & 34.23 & $* * * *$ & 34.23 & $* * * *$ \\
\hline 2 vs. $4 \mathrm{~kg} \mathrm{ha}^{-1}$ & 1 & 0.30 & $\mathrm{~ns}$ & 0.52 & ns & 0.32 & $\mathrm{~ns}$ & 6.51 & $*$ & 0.02 & $\mathrm{~ns}$ & 0.02 & ns \\
\hline
\end{tabular}

$\mathrm{z} *, * *, * * *$, and $* * * *=$ Significant at the $0.05,0.01,0.001$, and $<0.0001$ probability levels, respectively; ns $=$ not significant at $P \leq 0.05$. 
In 2001, the plots receiving a single application of $C$. minitans had less disease than the nontreated control, but disease incidence in plots receiving two applications was not significantly different from the nontreated control (Table 4). In 2002, three consecutive years of $C$. minitans applications had the least amount of disease (Table 4). The single application of $C$. minitans also reduced disease over the nontreated control, whereas there was no difference between the two consecutive years of application and the nontreated control (Table 4). By 2003, applications of C. minitans for 1,2 , and 3 years significantly reduced disease when compared with the nontreated plots, but there was no difference between the number of years $C$. minitans was applied and the amount of Sclerotinia blight that developed (Table 4). There was no effect of $C$. minitans or the application of fluazinam on yields or peanut quality as measured by \%ELK and \%FP (data not shown), consistent with previous research. Cv. Perry has a significantly larger number of extra larger kernels and fancy pods than NC-V 11 (data not shown).

Isolation of sclerotia and mycoparasitism. There were no significant interactions between $C$. minitans treatment and the time of soil sampling; therefore, the number of sclerotia isolated from soil was averaged across sampling dates (Table 5). One, two, and three consecutive applications of $C$. minitans reduced recovery of sclerotia from soil in the long-term field study compared with the nontreated control when averaged across all sampling dates (Table 5). Viability of recovered sclerotia ranged from 23 to $67 \%$, but there were no statistically significant differences between the various treatments. C. minitans was isolated from recovered sclerotia in all plots and infection ranged from 2 to $31 \%$ of the sclerotia infected, but no statis- tically significant differences in infection were found between the various treatments. Soil sampled on 11 September 2002 had fewer sclerotia when $C$. minitans was applied for two and three consecutive years and, by 2 October 2002, soil in all three treatments of $C$. minitans had significantly fewer sclerotia than the nontreated control (Table 5). When soil was sampled on 16 September 2003, there was no difference between the $C$. minitans treatments and the control, but the number of sclerotia was lower than in the previous sample taken in 2002 (Table 5). By 16 October 2003, the plots treated with $C$. minitans had slightly fewer sclerotia, whereas the number of sclerotia isolated in the control increased (Table 5).

Sclerotial baits. There were no significant interactions between the length of burial and treatment on viability or infection by $C$. minitans of the sclerotia in baits placed in the long-term field plot. Therefore, the data were combined across recovery dates for 2002 and 2003. In both years, there were no significant treatment effects on the percentage of sclerotia infected by $C$. minitans, even though $C$. minitans was isolated from 6 to $27 \%$ of the sclerotia. Viability of the sclerotia placed in the baits ranged from 5 to $28 \%$ after recovery from the soil. There were no statistically significant treatment effects on viability except for the single treatment of $C$. minitans at 2 $\mathrm{kg} \mathrm{ha}^{-1}$ in 2003, which had only $5 \%$ viability compared with the remaining treatments with $19 \%$ or greater viability (data not shown). Several other fungi also were isolated from the sclerotia in baits, including species in the genera Fusarium, Trichoderma, Penicillium, Aspergillus, Sporidesmium, and Mucor.

Short-term field sites. Sufficient Sclerotinia blight occurred in six of the eight locations selected in 2001 and 2002 to evaluate the $C$. minitans treatment. There were no significant interactions among $C$. minitans, fluazinam, and cultivar treatment effects for all locations and dates. Moderate resistance and fungicide provided adequate control of Sclerotinia blight at the six locations (Tables 6 and 7). Fungicide treatments did not have any effect on peanut quality (data not shown), but the \%ELK was higher where Perry was planted in Windsor, Jackson, Scotland Neck, and Gatesville compared with NC-V 11 (data not shown). C. minitans slightly reduced disease in four locations, Scotland Neck, Hertford, and Tyner, in 2001 and at Corapeake in 2002, though these reductions were not significant (Tables 6 and 7). There was no effect of $C$. minitans application on peanut yield in all locations and years (Tables 6 and 7). A higher \%ELK was found in plots treated with $C$. minitans

Table 5. Average number, viability, and infection by Coniothyrium minitans of sclerotia recovered from soil in the long-term field study

\begin{tabular}{lccccc}
\hline & \multicolumn{5}{c}{ Number of sclerotia $^{\mathbf{z}}$} \\
\cline { 2 - 6 } C. minitans treatment & $\mathbf{1 1 ~ S e p ~ 2 0 0 2}$ & $\mathbf{1 0}$ Oct 2002 & 16 Sep 2003 & $\mathbf{1 6}$ Oct 2003 & Average \\
\hline Control & $9 \mathrm{a}$ & $21 \mathrm{a}$ & $9 \mathrm{a}$ & $13 \mathrm{a}$ & $13 \mathrm{a}$ \\
1 year & $7 \mathrm{ab}$ & $13 \mathrm{~b}$ & $8 \mathrm{a}$ & $8 \mathrm{a}$ & $9 \mathrm{~b}$ \\
2 years & $4 \mathrm{~b}$ & $13 \mathrm{~b}$ & $9 \mathrm{a}$ & $8 \mathrm{a}$ & $8 \mathrm{~b}$ \\
3 years & $5 \mathrm{~b}$ & $11 \mathrm{~b}$ & $9 \mathrm{a}$ & $8 \mathrm{a}$ & $8 \mathrm{~b}$ \\
\hline
\end{tabular}

${ }^{\mathrm{z}}$ Sclerotia recovered from $500 \mathrm{~g}$ dried soil. Values followed by the same letter in each column are not significantly different at a $P \leq 0.05$ according to Fisher's protected least significant difference.

Table 4. Mean area under disease progress curve (AUDPC) and yield $\left(\mathrm{kg} \mathrm{ha}^{-1}\right)$ of main effects in the long-term field study for 2001, 2002, and 2003 peanut growing seasons ${ }^{\mathrm{y}}$

\begin{tabular}{|c|c|c|c|c|c|c|c|}
\hline \multirow[b]{2}{*}{ Main effect } & \multirow[b]{2}{*}{ Treatment } & \multicolumn{2}{|c|}{2001} & \multicolumn{2}{|c|}{2002} & \multicolumn{2}{|c|}{2003} \\
\hline & & AUDPC & Yield & AUDPC & Yield & AUDPC & Yield \\
\hline \multicolumn{8}{|c|}{ Coniothyrium minitans rate } \\
\hline & 0 & $188 \mathrm{a}$ & $5,810 \mathrm{a}$ & $842 \mathrm{a}$ & $3,050 \mathrm{~b}$ & $874 \mathrm{a}$ & $1,950 \mathrm{a}$ \\
\hline & $2 \mathrm{~kg} \mathrm{ha}^{-1}$ & $167 \mathrm{a}$ & $5,640 \mathrm{a}$ & $591 \mathrm{~b}$ & $3,000 \mathrm{~b}$ & $642 \mathrm{~b}$ & $1,430 \mathrm{~b}$ \\
\hline & $4 \mathrm{~kg} \mathrm{ha}^{-1}$ & $152 \mathrm{a}$ & $5,770 \mathrm{a}$ & $625 \mathrm{~b}$ & 3,370 a & $646 \mathrm{~b}$ & $1,440 \mathrm{~b}$ \\
\hline \multicolumn{8}{|c|}{ Years of $C$. minitans $^{\mathrm{z}}$} \\
\hline & 0 & $181 \mathrm{a}$ & $5,810 \mathrm{a}$ & $842 \mathrm{a}$ & $3,050 \mathrm{a}$ & $874 \mathrm{a}$ & $1,950 \mathrm{a}$ \\
\hline & 1 & $133 \mathrm{~b}$ & $5,780 \mathrm{a}$ & $653 \mathrm{~b}$ & $3,270 \mathrm{a}$ & $615 \mathrm{~b}$ & $1,370 \mathrm{~b}$ \\
\hline & 2 & $188 \mathrm{ab}$ & $5,630 \mathrm{a}$ & $702 \mathrm{ab}$ & $3,310 \mathrm{a}$ & $650 \mathrm{~b}$ & $1,450 \mathrm{~b}$ \\
\hline & 3 & $\ldots$ & $\ldots$ & $469 \mathrm{c}$ & $2,980 \mathrm{a}$ & $667 \mathrm{~b}$ & $1,490 \mathrm{~b}$ \\
\hline \multicolumn{8}{|l|}{ Fluazinam } \\
\hline & 0 & $207 \mathrm{a}$ & $5,660 \mathrm{~b}$ & 749 a & $3,050 \mathrm{a}$ & $1089 \mathrm{a}$ & $2,430 \mathrm{a}$ \\
\hline & $0.625 \mathrm{~kg}$ a.i. $\mathrm{ha}^{-1}$ & $132 \mathrm{~b}$ & $5,850 \mathrm{a}$ & $584 \mathrm{~b}$ & $3,260 \mathrm{a}$ & $313 \mathrm{~b}$ & $700 \mathrm{~b}$ \\
\hline \multicolumn{8}{|l|}{ Cultivar } \\
\hline & NC-V 11 & $234 \mathrm{a}$ & $5,810 \mathrm{a}$ & $826 \mathrm{a}$ & $3,080 \mathrm{a}$ & & \\
\hline & Perry & $106 \mathrm{~b}$ & $5,700 \mathrm{a}$ & $507 \mathrm{~b}$ & $3,220 \mathrm{a}$ & 701 & 1,560 \\
\hline
\end{tabular}

y Data pooled over other treatment factors and contrasts were used to separate the main effects of $C$. minitans rate and yearly treatment, values followed by the same letter in each column are not significantly different at a $P \leq 0.05$ for each main effect. There were no significant interactions between main effects in all years for disease. AUDPC was calculated using disease incidence taken from two center rows of each plot and yield estimated from two center rows.

${ }^{\mathrm{z}}$ Only 1 and 2 years of application of C. minitans were made in 2001, and 2003 is the year following the yearly treatments. 
in Windsor, Scotland Neck, and Gatesville locations; there was no effect of $C$. minitans on the \%FP (data not shown). In 2002, C. minitans reduced the number of sclerotia recovered $22 \%$ at both Gatesville and Corapeake where disease pressure was high (Table 7). Subsequently, only one of these plots had slightly less disease where C. minitans was applied, which was not significantly different from the nontreated control. C. minitans was isolated from a small number of the sclerotia recovered from soil in both Gatesville and Corapeake short-term field plots, but not in Tyner.

\section{DISCUSSION}

The number of sclerotia of $S$. minor in the soil and the incidence of Sclerotinia blight of peanut was reduced in our 5-year field study by applications of $C$. minitans. However, this activity was not observed until at least 1 year after $C$. minitans was introduced. C. minitans was active against the sclerotia of $S$. minor in the soil even when favorable environmental conditions and continuous planting of peanut promoted disease. Both the 2 and $4 \mathrm{~kg} \mathrm{ha}^{-1}$ rate of $C$. minitans applied to the soil decreased the number of sclerotia recovered and disease incidence. The lack of increased control with the higher application of $C$. minitans supports the hypothesis that there is a carrying capacity for this mycoparasite in the soil we examined (18). Once a certain population size is achieved in the soil, the addition of additional biological control agent will not reduce disease further, as is seen often with chemical application. Most previous studies have focused on the activity of $C$. minitans on sclerotia of $S$. sclerotiorum $(6,7,14,23,24$, $48,49)$. Our results support other studies $(33,40)$ that found that $C$. minitans has useful activity on $S$. minor in the field. Additionally, our laboratory studies clearly demonstrated that $C$. minitans has good activity on sclerotia of $S$. minor under a wide range of environmental conditions (27).

No significant reduction in disease was observed in our long-term study until approximately 18 months after the first application of C. minitans in December 1999. Many sclerotia may have escaped infection by $C$. minitans and were available to germinate and infect the first peanut crop in 2001, resulting in the disease spreading quickly through the canopy in both treated and nontreated plots. However, in 2002, there was less disease in plots receiving one or three consecutive years of application. By 2003, one, two, and three con- secutive years of $C$. minitans soil application reduced disease. These results suggest that more than 1 year is needed for the mycoparasite to lower the inoculum density enough to reduce disease. This also was observed in the short-term plots, where the numbers of sclerotia recovered from the soil were reduced by $C$. minitans treatment but subsequent reduction in disease was not observed. Spores of $C$. minitans must come in contact with the sclerotia in order for infection to occur (47). Movement of $C$. minitans spores can be augmented by the movement of soil in field preparation and by water or by soil fauna $(43,44,52-54)$, increasing the chance of exposure of the sclerotia to spores of $C$. minitans, because $C$. minitans does not grow saprophytically through soil (51). $C$. minitans will produce conidia after infection of sclerotia; therefore, secondary spread of the mycoparasite also can contribute to increased distribution in the soil. The longer $C$. minitans is present in the soil, the more likely it will come in contact with, infect, and reduce the inoculum density of sclerotia, ultimately decreasing disease incidence $(7,12)$.

Although the effects of $C$. minitans on reducing numbers of sclerotia recovered in soil were promoted with longer exposure,

Table 6. Mean area under disease progress curve (AUDPC) and yield $\left(\mathrm{kg} \mathrm{ha}^{-1}\right)$ of main treatments applied to short-term field studies located in peanut production areas of North Carolina in $2001^{\mathrm{x}}$

\begin{tabular}{|c|c|c|c|c|c|c|c|c|c|c|c|}
\hline \multirow[b]{2}{*}{ Main effect } & \multirow[b]{2}{*}{ Treatment } & \multicolumn{2}{|c|}{ Windsor } & \multicolumn{2}{|c|}{ Jackson } & \multicolumn{2}{|c|}{ Scotland Neck } & \multicolumn{2}{|c|}{ Hertford } & \multicolumn{2}{|c|}{ Tyner } \\
\hline & & AUDPC $^{\mathbf{y}}$ & Yield $^{\mathbf{z}}$ & AUDPC & Yield & AUDPC & Yield & AUDPC & Yield & AUDPC & Yield \\
\hline \multicolumn{12}{|c|}{ Coniothyrium minitans } \\
\hline & 0 & $237 \mathrm{a}$ & $4,332 \mathrm{a}$ & $12 \mathrm{a}$ & $2,503 \mathrm{a}$ & $6 \mathrm{a}$ & $4,351 \mathrm{a}$ & $436 \mathrm{a}$ & $4,595 \mathrm{a}$ & $3 \mathrm{a}$ & $3,645 \mathrm{a}$ \\
\hline & $4 \mathrm{~kg} \mathrm{ha}^{-1}$ & $224 \mathrm{a}$ & $4,215 \mathrm{a}$ & $19 \mathrm{a}$ & $2,782 \mathrm{a}$ & $1 \mathrm{a}$ & $4,437 \mathrm{a}$ & $357 \mathrm{a}$ & $4,730 \mathrm{a}$ & $0 \mathrm{a}$ & $3,950 \mathrm{a}$ \\
\hline \multicolumn{12}{|l|}{ Fluazinam } \\
\hline & 0 & $326 \mathrm{a}$ & $4,211 \mathrm{a}$ & $23 \mathrm{a}$ & $2,557 \mathrm{a}$ & $2 \mathrm{a}$ & $4,247 \mathrm{~b}$ & $557 \mathrm{a}$ & $4,456 \mathrm{~b}$ & $0 \mathrm{a}$ & $3,719 \mathrm{a}$ \\
\hline \multirow{2}{*}{\multicolumn{12}{|c|}{$0.025 \mathrm{~kg}$ a.1. na }} \\
\hline & & & & & & & & & & & \\
\hline & Perry & $253 \mathrm{a}$ & $4,209 \mathrm{a}$ & 10 & $2,5 / 3 \mathrm{a}$ & $0 \mathrm{a}$ & $3,949 \mathrm{~b}$ & $\cdots$ & $\cdots$ & $\cdots$ & $\cdots$ \\
\hline & NC-V 11 & $228 \mathrm{a}$ & $4,283 \mathrm{a}$ & $24 \mathrm{a}$ & $2,712 \mathrm{a}$ & $2 \mathrm{a}$ & $4,839 \mathrm{a}$ & $\ldots$ & $\ldots$ & $\ldots$ & $\ldots$ \\
\hline
\end{tabular}

${ }^{x}$ For each main effect, values followed by the same letter are not significantly different at a $P \leq 0.05$ according to Fisher's protected least significant difference.

y AUDPC was calculated using disease incidence taken from two center rows of each plot.

${ }^{\mathrm{z}}$ Yield estimated from two center rows.

Table 7. Mean area under disease progress curve (AUDPC) yield $\left(\mathrm{kg} \mathrm{ha}^{-1}\right)$, and number of sclerotia isolated from soil of main treatments applied to shortterm field studies located in peanut production areas of North Carolina in $2002^{\mathrm{w}}$

\begin{tabular}{|c|c|c|c|c|c|c|c|c|c|c|}
\hline \multirow[b]{2}{*}{ Main effect } & \multirow[b]{2}{*}{ Treatment } & \multicolumn{3}{|c|}{ Tyner } & \multicolumn{3}{|c|}{ Gatesville } & \multicolumn{3}{|c|}{ Corapeake } \\
\hline & & $\operatorname{AUDPC}^{\mathbf{x}}$ & Yield $^{y}$ & Sclerotia $^{z}$ & AUDPC & Yield & Sclerotia & AUDPC & Yield & Sclerotia \\
\hline \multicolumn{11}{|c|}{ Coniothyrium minitans } \\
\hline & 0 & $66 \mathrm{a}$ & $\ldots$ & $2 \mathrm{a}$ & $774 \mathrm{a}$ & $3,040 \mathrm{a}$ & $9 \mathrm{a}$ & $467 \mathrm{a}$ & $1,217 \mathrm{a}$ & $9 \mathrm{a}$ \\
\hline & $4 \mathrm{~kg} \mathrm{ha}^{-1}$ & $65 \mathrm{a}$ & $\ldots$ & $2 \mathrm{a}$ & $799 \mathrm{a}$ & $2,900 \mathrm{a}$ & $7 \mathrm{~b}$ & $434 \mathrm{a}$ & $1,222 \mathrm{a}$ & $7 \mathrm{~b}$ \\
\hline \multicolumn{11}{|l|}{ Fluazinam } \\
\hline & 0 & $119 \mathrm{~b}$ & $\ldots$ & $2 \mathrm{a}$ & $898 \mathrm{~b}$ & $2,952 \mathrm{a}$ & $16 \mathrm{a}$ & $556 \mathrm{~b}$ & $1,068 \mathrm{~b}$ & $8 \mathrm{a}$ \\
\hline & $0.625 \mathrm{~kg}$ a.i. $\mathrm{ha}^{-1}$ & $11 \mathrm{a}$ & $\ldots$ & $1 \mathrm{a}$ & $676 \mathrm{a}$ & $2,989 \mathrm{a}$ & $9 \mathrm{~b}$ & $323 \mathrm{a}$ & $1,372 \mathrm{a}$ & $8 \mathrm{a}$ \\
\hline \multicolumn{11}{|l|}{ Cultivar } \\
\hline & Perry & $67 \mathrm{a}$ & $\ldots$ & $\ldots$ & $505 \mathrm{a}$ & $3,077 \mathrm{a}$ & $\ldots$ & $434 \mathrm{a}$ & $1,224 \mathrm{a}$ & $\ldots$ \\
\hline & NC-V 11 & $64 \mathrm{a}$ & $\ldots$ & $\ldots$ & $1,069 \mathrm{~b}$ & $2,864 \mathrm{a}$ & $\ldots$ & $464 \mathrm{a}$ & $1,216 \mathrm{a}$ & $\ldots$ \\
\hline
\end{tabular}

${ }^{\text {w}}$ For each main effect, values followed by the same letter are not significantly different at a $P \leq 0.05$ according to Fisher's protected least significant difference.

${ }^{x}$ AUDPC was calculated using disease incidence taken from two center rows of each plot.

${ }^{y}$ Yield estimated from two center rows.

${ }^{\mathrm{z}}$ Number of sclerotia isolated from $500 \mathrm{~g}$ of dry soil taken from under the NC-V11 peanut canopy. 
disease incidence of Sclerotinia blight increased each year. This was expected because planting of peanut three consecutive years greatly increases inoculum density as a result of sclerotia which are shed into the soil from diseased tissue. Continuous cropping was used in our study because we wanted to examine the long-term effect of $C$. minitans on Sclerotinia blight. Current production practices of rotating peanut with corn or cotton, nonhosts of $S$. minor, take this into account, limiting the number of consecutive years peanut is planted in a field $(26,33)$. Long-term rotation has been shown to help reduce disease and allows the sclerotia to be broken down by various soil microorganisms during periods when there is no host to infect $(30,43,44)$.

A greater reduction in disease will be needed in order to significantly increase peanut yield as found in the fungicide treatments in 2001 and 2003. In 2003, disease was reduced $71 \%$ by fluazinam, leading to a $1,730 \mathrm{~kg} / \mathrm{ha}$ increase in yield, whereas $C$. minitans yearly application did not show an affect in peanut on yield in both 2001 and 2002. In 2002, the $4 \mathrm{~kg} \mathrm{ha}^{-1}$ rate of $C$. minitans was found to increase peanut yield; however, in 2003, lower peanut yield occurred in all $C$. minitanstreated plots. Lower yields following multiple applications of C. minitans in 2003 were not expected. However, yields were low regardless of the rate $\left(2\right.$ or $\left.4 \mathrm{~kg} \mathrm{ha}^{-1}\right)$ of $C$. minitans, which reflects both the late planting date and poor harvest conditions. Overall yields averaged $4,100 \mathrm{~kg} / \mathrm{ha}$ less compared with the average yield in 2001 $(5,740 \mathrm{~kg} / \mathrm{ha})$. Nevertheless, additional research is needed to determine the cause of the lower yield observed in C. minitanstreated plots in 2003 before long-term intensive programs are recommended.

The current control measures used for Sclerotinia blight, including moderate resistance and fungicide applications, did not influence the activity of $C$. minitans. Application of fluazinam to the peanut canopy reduced disease compared with nontreated plots and significantly increased yield in both 2001 and 2003 . Fluazinam is a very effective fungicide against $S$. minor when applied at proper times by preventing infection, $(10,11$, 39,40 ), but it does not directly reduce the numbers of sclerotia. The integration of $C$. minitans with fluazinam aims to further disrupt the disease cycle of $S$. minor by reducing the inoculum density. Laboratory experiments have shown that fluazinam limits spore germination, mycelial growth, and mycoparasitic activity of $C$. minitans (27). Even though we detected no treatment interactions of fluazinam and $C$. minitans in the field, applications of $C$. minitans should be made cautiously when fluazinam, azoxystrobin, chlorothalonil, pyraclostrobin, and tebuconazole are being used in the field. These fungicides may compromise the performance of $C$. minitans and, therefore, application of C. minitans over the peanut canopy is not recommended for peanut production as it is in horticultural crops (12). Less disease also was seen in plots planted with cv. Perry. Perry has partial resistance that limits the amount of infection by $S$. minor in the peanut canopy (17). Integration of the mycoparasite with fluazinam and moderate resistance may help further manage this disease by reducing initial inoculum and rate of infection, thereby slowing the disease epidemic in peanut.

Sclerotia were isolated from soil each month during the peanut growing season. The ability to predict disease incidence by enumerating sclerotia has been difficult for Sclerotinia blight. Numbers of sclerotia tend to fluctuate throughout the growing season as the sclerotia germinate to infect peanut plants and as they shed back into the soil from diseased tissue. Averaging samples taken in September and October did show a reduction of sclerotia with $C$. minitans treatment. However, 2 to $31 \%$ of the sclerotia recovered in samples from each treatment were infected by $C$. minitans. These percentages only represent those sclerotia that were recovered from the soil, whereas the sclerotia that were degraded by $C$. minitans would not be represented in the sample. $C$. minitans also was isolated from sclerotia placed in the soil during 2002 and 2003. Reduced numbers of sclerotia and their colonization demonstrate the ability of $C$. minitans to infect sclerotia and persist in peanut fields. The baits also showed that there are a number of other fungi present in the soil that can aid in the destruction of sclerotia, including species of Fusarium, Trichoderma, Penicillium, Aspergillus, Sporidesmium, and Mucor. These genera all have been shown to be mycoparasites of Sclerotinia spp.; therefore, potential exists to reduce the number of sclerotia in soil if natural mycoparasitic populations are promoted $(2-4,20,22,55)$.

Results from these field studies indicate that soil applications of $C$. minitans may aid in reducing losses to Sclerotinia blight in peanut. This mycoparasite easily can be integrated with moderately resistant cultivars and fungicide applications that are used in managing Sclerotinia blight on peanut. We have found that $C$. minitans is able to persist and infect sclerotia of $S$. minor in peanut fields of North Carolina. This biological control agent can be applied in the fall across crop residue and incorporated into the top layers of the soil where it will most effectively parasitize the sclerotia of $S$. minor. $C$. minitans will not provide a rapid cure to fields heavily infested by $S$. minor; however, these studies provide evidence that, over time, $C$. minitans can help reduce inoculum levels of $S$. minor and may aid in the management of Sclerotinia blight of peanut. Studies need to be conducted in fields with low inoculum levels to see whether applications of $C$. minitans will reduce the disease low enough so that fungicides are no longer needed, which could reduce input costs for controlling Sclerotinia blight.

\section{ACKNOWLEDGMENTS}

This research was supported by funds administered through the North Carolina Peanut Growers Association, National Peanut Board, and the IR4 Program. We thank Umphlett Brother's, G. P. Kittrell and Son, J. H. Ward, G. and M. Perry, J. Hamil, Bell Brothers, and LATROS Farms for providing land for these studies; M. L. Gumpertz for providing statistical consultation; and D. Johnson and C. Murphy for providing technical support.

\section{LITERATURE CITED}

1. Adams, P. B., and Ayers, W. A. 1979. Ecology of Sclerotinia species. Phytopathology 69:896 899.

2. Adams, P. B., and Ayers, W. A. 1982. Biological control of Sclerotinia lettuce drop in the field by Sporidesmium sclerotivorum. Phytopathology 72:485-488

3. Adams, P. B., and Fravel, D. R. 1990. Economical biological control of Sclerotinia lettuce drop by Sporidesmium sclerotivorum. Phytopathology 80:1120-1124.

4. Ayers, W. A., and Adams, P. B. 1979. Mycoparasitism of sclerotia of Sclerotinia and Sclerotium species by Sporidesmium sclerotivorum. Can. J. Microbiol. 25:17-23.

5. Beute, M. K., Porter, D. M., and Hadley, B. A. 1975. Sclerotinia blight of peanut in North Carolina and Virginia and its chemical control. Plant Dis. Rep. 59:697-701.

6. Budge, S. P., McQuilken, M. P., Fenlon, J. S. and Whipps, J. M. 1995. Use of Coniothyrium minitans and Gliocladium virens for biological control of Sclerotinia sclerotiorum in glasshouse lettuce. Biol. Control 5:513-522.

7. Budge, S. P., and Whipps, J. M. 1991. Glasshouse trials of Coniothyrium minitans and Trichoderma species for the biological control of Sclerotinia sclerotiorum in celery and lettuce. Plant Pathol. 40:59-66.

8. Butzler, T. M., Bailey, J. E., and Beute, M. K 1998. Integrated management of Sclerotinia blight in peanut: utilizing canopy morphology, mechanical pruning, and fungicide timing. Plant Dis. 82:1312-1318.

9. Campbell, W. A. 1947. A new species of Coniothyrium parasitic on sclerotia. Mycologia 39:190-195.

10. Damicone, J. P., and Jackson, K. E. 1996. Disease and yield responses to fungicides among peanut cultivars differing in reaction to Sclerotinia blight. Peanut Sci. 23:81-85.

11. Damicone, J. P., Melouk, H. A., and Jackson, K. E. 1997. Reaction of runner cultivars and breeding lines of peanut to Sclerotinia blight and their responses to fungicide treatment. (Abstr.) Proc. Am. Peanut Res. Educ. Soc. 30:24.

12. Gerlagh, M., Goossen-van de Geijn, H. M., Fokkema, N. J., and Vereijken, P. F. G. 1999 Long-term biosanitation by application of $\mathrm{Co}$ niothyrium minitans on Sclerotinia sclerotiorum infected crops. Phytopathology 89:141-147.

13. Hollowell, J. E., Shew, B. B., and Isleib, T. G. 2003. Evaluating isolate aggressiveness and host resistance from peanut leaflet inoculations with Sclerotinia minor. Plant Dis. 87:402-406.

14. Huang, H. C. 1980. Control of Sclerotinia wilt of sunflower by hyperparasites. Can. J. Plant Pathol. 2:26-32.

15. Huang, H. C., Bremer, E., Hynes, R. K., and Erickson, R. S. 2000. Foliar application of fungal biocontrol agents for the control of 
white mold of dry bean caused by Sclerotinia sclerotiorum. Biol. Control 18:270-276.

16. Huang, H. C., and Erickson, R. S. 2002. Overwintering of Coniothyrium minitans, a mycoparasite of Sclerotinia sclerotiorum, on the Canadian prairies. Australas. Plant Pathol. 31:291-293.

17. Isleib, T. G., Rice, P. W., Mozingo, R. W., II, Bailey, J. E., Mozingo, R. W., and Pattee, H. E. 2003. Registration of 'Perry' peanut. Crop Sci. 43:739-740.

18. Johnson, K. B. 1994. Dose-response relationship and inundative biological control. Phytopathology 84:780-784.

19. Jordan, D. L., Bailey, J. E., Barnes, J. S., Bogle, C. R., Bullen, S. G., Brown, A. B., Edminsten, K. L., Dunphy, E. J., and Johnson, P. D. 2002. Yield and economic return of ten peanut-based cropping systems. Agron. J. 94:1289-1294.

20. Karhuvaara, L. 1960. On parasites of the sclerotia of some fungi. Acta Agric. Scand. 10:127-134.

21. Lumsden, R. D. 1979. Histology and physiology of pathogenesis in plant diseases caused by Sclerotinia species. Phytopathology 69:890896.

22. Makkonen, R., and Pohjakallio, O. 1960. On the parasites attacking the sclerotia of some fungi pathogenic to higher plants and on the resistance of these sclerotia to their parasites. Acta Agric. Scand. 10:105-126.

23. McLaren, D. L., Kozub, G. C., and Rimmer, S. R. 1994. Biological control of Sclerotinia wilt of sunflower with Talaromyces flavus and $\mathrm{Co}$ niothyrium minitans. Plant Dis. 78:231-235.

24. McQuilken, M. P., Michell, S. J., Budge, S. P., Whipps, J. M., Fenlon, J. S., and Archer, S. A. 1995. Effect of Coniothyrium minitans on sclerotial survival and apothecial production of Sclerotinia sclerotiorum in field-grown oilseed rape. Plant Pathol. 44:883-896.

25. McQuilken, M. P., and Whipps, J. M. 1995. Production, survival and evaluation of solidsubstrate inocula of Coniothyrium minitans against Sclerotinia sclerotiorum. Eur. J. Plant Pathol. 101:101-110.

26. Melzer, M. S., Smith, E. A., and Boland, G. J. 1997. Index of plant hosts of Sclerotinia minor. Can. J. Plant Pathol. 19:272-280.

27. Partridge, D. E. 2005. Potential for management of Sclerotinia blight of peanut (Arachis hypogaea L.) caused by Sclerotinia minor with the biological control agent Coniothyrium minitans. Ph.D. dissertation, Department of Plant Pathology, North Carolina State University, Raleigh.

28. Phipps, P. M. 1995. An algorithm for prediction outbreaks of Sclerotinia blight of peanut and improving the efficacy of fungicide sprays. (Abstr.) Proc. Am. Peanut Res. Educ. Soc. 27:23.

29. Phipps, P. M. 1995. An assessment of environmental conditions preceding outbreaks of Sclerotinia blight on peanut in Virginia. Peanut Sci. 22:90-93.

30. Phipps, P. M., Deck, S. H., and Walker, D. R. 1997. Weather-based crop and disease advisories for peanuts in Virginia. Plant Dis. 81:236244.

31. Porter, D. M 1984. Sclerotinia blight. In: Compendium of Peanut Diseases. D. M. Porter, D. H. Smith, and R. Rodriguez-Kabana, eds. American Phytopathological Society Press, St. Paul, MN.

32. Porter, D. M., and Beute, M. K. 1974. Sclerotinia blight of peanuts. Phytopathology 64:263-264.

33. Porter, D. M., and Melouk, H. A. 1997. Sclerotinia Blight In: Compendium of Peanut Diseases, Second Ed. N. Kokalis-Burelle, D. M. Porter, R. Rodriguez-Kabana, D. H. Smith, and P. Subrahamanyam, eds. American Phytopathological Society Press, St. Paul, MN.

34. Porter, D. M., and Steele, J. L. 1983. Quantitative assay by elutriation of peanut field soil for sclerotia of Sclerotinia minor. Phytopathology 73:636-640.

35. Ridgway, H. J., Rabeendran, N., Eade, K., and Stewart, A. 2001. Application timing of Coniothyrium minitans A69 influences biocontrol of Sclerotinia minor in lettuce. Proc. Conf. Palmerston North, New Zealand. N. Z. Plant Prot. 54:14-16

36. Shaner, G., and Finney, R. E. 1977. The effect of nitrogen fertilization on the expression of slow-mildewing resistance in Knox wheat. Phytopathology 67:1051-1056.

37. Shew, B. B. 2004. Peanut disease management. Chapter 6 in: 2004 Peanut Information. D. L. Jordan, J. F. Spears, R. L. Brandenburg, A. B. Brown, B. B. Shew, G. T. Roberson, and S. G. Bullen, eds. North Carolina Cooperative Extension Service, Raleigh.

38. Sidebottom, J. R., and Beute, M. K. 1989. Inducing soil suppression to Cylindrocladium black rot of peanut through crop rotations with soybean. Plant Dis. 73:629-685.

39. Smith, F. D., and Phipps, P. M. 1991. Agar plate, soil plate, and field evaluation of fluazinam and other fungicides for control of Sclerotinia minor on peanut. Plant Dis. 75:11381143.

40. Smith, F. D., Phipps, P. M., and Stipes, R. J. 1992. Fluazinam: A new fungicide for control of Sclerotinia blight and other soilborne pathogens of peanut. Peanut Sci. 19:115-120.

41. Stewart, A., Eade, K., Rabeendran, N., and
Ridgway, H. 2001. Mechanisms of biological control of Sclerotinia lettuce drop by Coniothyrium minitans-more than just sclerotial parasitism. Bull. OILB/SROP 24:1-4.

42. Tribe, H. T. 1957. On the parasitism of Sclerotinia trifoliorum by Coniothyrium minitans. Trans. Br. Mycol. Soc. 40:489-499.

43. Trutman, P., Keane, P. J., and Merriman, P. R. 1980. Reduction of sclerotial inoculum of Sclerotinia sclerotiorum with Coniothyrium minitans. Soil Biol. Biochem. 12:461-465.

44. Turner, G. J., and Tribe, H. T. 1976. On Coniothyrium minitans and its parasitism of Sclerotinia species. Trans. Br. Mycol. Soc. 66:97105.

45. United States Department of Agriculture. 1998. Farmers' Stock Peanuts Inspection Instructions. U. S. Dep. Agric., Washington, DC.

46. Wadsworth, D. F. 1979. Sclerotinia blight of peanut in Oklahoma and occurrence of the sexual stage of the pathogen. Peanut Sci. 6:7779

47. Whipps, J. M., and Budge, S. P. 1990. Screening for sclerotial mycoparasites of Sclerotinia sclerotiorum. Mycol. Res. 94:607-612.

48. Whipps, J. M., Budge, S. P., and Mitchell, S. J. 1993. Observations on sclerotial mycoparasites of Sclerotinia sclerotiorum. Mycol. Res. 97:697-700

49. Whipps, J. M., Mcquilken, M. P., and Budge, S. P. 1993. Use of fungal antagonists for biocontrol of damping-off and Sclerotinia diseases. Pestic. Sci. 37:309-313.

50. Williams, E. J., and Drexler, J. S. 1981. A nondestructive method for determining peanut pod maturity, pericarp, mesocarp, color, morphology, classification. Peanut Sci. 8:134-141.

51. Williams, R. H., and Whipps, J. M. 1995. Growth and transmission of Coniothyrium minitans in soil. Bull. Int. Org. Biol. Control 18:39-43

52. Williams, R. H., Whipps, J. M., and Cooke, R. C. 1998. Water splash dispersal of Coniothy rium minitans in the glasshouse. Ann. Appl Biol. 132:77-90.

53. Williams, R. H., Whipps, J. M., and Cooke, R. C. 1998. Role of soil mesofauna in dispersal of Coniothyrium minitans: transmission to sclerotia of Sclerotinia sclerotiorum. Soil Biol. Biochem. 30:1929-1935.

54. Williams, R. H., Whipps, J. M., and Cooke, R. C. 1998. Role of soil mesofauna in dispersal of Coniothyrium minitans: mechanisms of transmission. Soil Biol. Biochem. 30:19371945.

55. Zazzerini, A., and Tosi, L. 1985. Antagonistic activity of fungi isolated from sclerotia of Sclerotinia sclerotiorum. Plant Pathol. 34:415421. 